\title{
Doing theology with children: Exploring emancipatory methodologies
}

\begin{abstract}
Authors:
Stephan De Beer ${ }^{1}$ (0

Hannelie Yates ${ }^{2}$ ]

Affiliations:

${ }^{1}$ Centre for Contextual Ministry, Faculty of Theology,

University of Pretoria,

Pretoria, South Africa

${ }^{2}$ Unit for Reformational

Theology and the

Development of the

South African Society

Sub-programme, Department of Practical Theology, Faculty of Theology, North-West University, Potchefstroom, South Africa
\end{abstract}

Corresponding author:

Stephan de Beer,

stephan.debeer@up.ac.za

Dates:

Received: 08 Oct. 2019

Accepted: 22 Oct. 2019

Published: 12 Dec. 2019

How to cite this article: De Beer, S. \& Yates, H., 2019,

'Doing theology with children: Exploring emancipatory

methodologies', HTS

Teologiese Studies/

Theological Studies 75(1),

a5840. https://doi.org/

10.4102/hts.v75i1.5840

Copyright:

(c) 2019. The Authors. Licensee: AOSIS. This work

is licensed under the

Creative Commons

Attribution License.

Read online:

Scan this QR code with your smart phone or mobile device to read online.
This article serves as an introduction to a collection of articles that explores emancipatory methodologies for doing theology and research with children. We focus on both the agency and the participation of children as an ethics and children's rights imperative as well as the potential impact and outcomes of theology and research that focus on children. The article emphasises that such research should be preceded by an epistemological shift that recognises the validity of local, experiential and different knowledges while insisting on participatory approaches in generating and constructing knowledge. It emphasises a rights-based approach and provides guidelines for ethical and collaborative research with children, moving beyond the paralysis of an ethics conundrum. The life and work of Janet Prest Talbot, who embodies commitment to children's rights, children's participation, child justice and God's joy over children forms a backdrop of and inspiration for this article.

Keywords: Child theology; Children's rights; Emancipatory methodologies; Research ethics; Research with children; Theology with children.

\section{Doing theology with children: An epistemological shift}

Negating the valid knowledges and experiences of children ${ }^{1}$ is an expression of epistemicide. At best, it is a lost opportunity to discover the world through children's eyes, but it is also a failure to listen deep enough to understand children's struggles and aspirations. At worst though, it belies an understanding of children that views them as less human and therefore unable to contribute meaningfully to the construction of knowledge.

\section{DeVries (2001) gives the following guidance:}

Communities of faith have much to learn from children's experience of God and their view of the world. Theology that values the perspectives of children will address quite different questions from the ones that have dominated the Christian tradition. (p. 61)

The following four issues are pertinent to this article: (1) The absence of children from most dominant forms of theological education and the necessity to change that; (2) epistemological arrogance that negates children's knowledge and agency and the necessity for an epistemological shift; (3) the ethics conundrum that seeks to protect children and institutions, often by excluding children, while failing ethically - to ensure that children's right to participation is honoured and upheld and (4) the beauty and power of emancipatory methodologies that make equal space for children at the table.

We focus on the last three aspects in this article, but the absence of children from our theological engagements remains a nagging concern. When children are considered, it is often as a brief subcategory of youth ministry, and then only children and youths who have found their way into the inner workings of ecclesial communities. The large percentages of children who are marginal and vulnerable in South African societies ${ }^{2}$ are unheard of, and unheard, in both churches and most theological classrooms.

1.For the purpose of this special collection, the concept of children refers to persons under the age of 18 years in accordance with the
Constitution of South Africa, the South African Children's Act (Act 38 of 2005), the United Nations Convention on the Rights of the Child
(UNCRC) and the African Charter on the Rights and Welfare of the Child (ACRWC). However, we acknowledge that defining children on
the basis of age is not without limitations. We recognise that 'the transition between childhood and adulthood is often determined by
social factors such as child-headed households, teenage pregnancies, sexual abuse and child labour, and cultural practices, such as
initiation' (Yates 2010:154). A contextual and balanced view on children is sought by focusing on children within their unique and
diverse social contexts while having in mind the biological basis of childhood. When putting too much emphasis on the biological
developmental stages of childhood, dominant understandings and norms for childhood can be created which may result in the majority
of Africa's children being stereotyped as inferior, deviant or even pathological.

2.Children's position in society intersects with the position of their families. Children whose families have been historically marginalised are in most cases unable to access the services that they need and to which they are entitled. This exclusion of children from access to basic services, especially in rural areas in South Africa, forces children to the margins of society and to experiences of vulnerability on a daily basis (cf. Hall et al. 2018).

Note: Doing Theology with Children: Exploring Emancipatory Methodologies, sub-edited by Stephan de Beer (UP Centre for Contextual Ministry) and Hannelie Yates (North-West University). 
What is required is an epistemological shift that locates knowledge respectfully in and with children. This requires that we learn to listen carefully so that children's narratives and experiences raise fresh theological questions and help formulate appropriate theological responses. This has the potential to give expression to a form of epistemic justice, as it would acknowledge children as true participants not only to be seen but also to be heard.

Such an epistemological shift should not only acknowledge children's knowledges and lived experiences but also their agency and ability to act in ways that could protect their interests, enhance their own well-being and inform our sociotheological constructs.

We here attempt to frame an approach that can facilitate such an epistemological shift and can accomplish children's full and rightful participation as an emancipatory approach to doing child theology.

We are proposing such a shift as equally important for academics, activists, practitioners and parents. Any discipline that involves children or space-making - ranging from education, social work and psychology, to theology, city planning or development studies - should consider such a shift.

\section{A rights-based emphasis}

Motivated by the life and work of Janet Prest Talbot, ${ }^{3}$ we are advocating for a rights-based emphasis in doing theology and research with children. As such, we are proposing a rights-based emphasis that brings a shift from an inward focus on what is understood as 'our children, their well-being and best interest' to a more outward focus on all children having a right to bodily life in this world.

A rights-based approach of working towards a democratic and just society for children is often defined by contrasting it with a needs-based approach. A needs-based approach demands no accountability, moral or legal obligation on the state and/or other statutory bodies to protect, provide or assist, while a rights-based approach adds legal and moral obligations and accountability (International Save the Children Alliance 2002:21; Harris-Curtis 2003:558-564; Yates 2010:159). Equally, a rights-based approach acknowledges children as the holders of rights and key actors and participants in society. They should therefore be encouraged and empowered to claim their rights whilst respecting the freedoms of others. The needs-based approach view children merely as passive victims, passive recipients of aid and even as objects to be provided for by experts (cf. Ansell 2005:50; International Save the Children Alliance 2002:21).

3.This special edition of HTS, "Doing theology with children: exploring emancipatory methodologies' is dedicated to the memory of Janet Prest Talbot, who sadly passed away on Wednesday 07 November 2018. Janet was a research associate of the Centre for Contextual Ministry at the University of Pretoria and collaborator in the Child Theology Africa Network. She was a passionate advocate of children, committed (t) to children's rights, the right to play and the participation of children in processes affecting them. Radically inclusive, and steeped in a solid feminist spirituality and deep love of Jesus, justice, children and nature, she would be missed by all who wer deeply impacted by her clarity of thought, capacity of heart, and creativity of spirit and action. Very few lived and breathed an emancipatory praxis with children as she did. For her it was not merely a matter of methodology but second nature.
This comparison between rights-based and needs-based emphasis also affects the work of theologians and the ministries of ecclesial communities. De Beer (2008:49) makes a distinction between a private theology and a communal or public theology. He considers the implications for theology when the rights of all children receive emphasis. The implications can be summarised as seen in Table 1 .

TABLE 1: Distinction between a so-called private and public theology.

\begin{tabular}{ll}
\hline Private theology & Communal/public theology \\
\hline Personal & Whole child \\
Needs & Assets/rights \\
Soul & Body \\
Compassion & Justice \\
Individualistic & Communal \\
Project & Community \\
\hline
\end{tabular}

Source: De Beer (2008:49)

We choose to give preference to a contextual theological paradigm in doing child theology and research with children. This paradigm seeks more contextual and integrated views on childhood and children in their web of relationships both private, communal and public- while doing justice by means of rights-based processes of structural change. A rights-based emphasis, we argue, can provide interdisciplinary and trans-disciplinary conceptual frameworks for theologians, researchers and practitioners operating in the field of child justice. A rights-based emphasis may help us find the means to shift from a distant private, fragmented and bodiless praxis to a public incarnated praxis of doing and seeking justice in the daily world of children (cf. De Beer 2008:47-62). We envisioned a transformational ecclesiology characterised among other things by a rights-based emphasis in doing theology and research with children (cf. Palm 2018; Van der Ven, Dreyer \& Pieterse 2003).

\section{The discourse on children's rights}

The development of the discourse on children's rights is perhaps most visible when reviewing the findings of the United Nations Convention on the Rights of the Child (UNCRC 1989). This event was held in answer to the need to reflect on the shifts in ideas about and approaches to children's needs and rights. This shift can be seen in the contents, terminology and approaches of the 1924 League of Nations Declaration on the Rights of the Child, the 1959 United Nations (General Assembly) Declaration on the Rights of the Child, and the 1989 UNCRC (cf. Yates \& Swart 2010:228). There is a shift from children being viewed as objects to children as subjects and from merely protecting children (welfare rights) to the participation and liberation of children (self-determination rights ${ }^{4}$ ) (cf. Yates 2010:157-158).

4.Children's participation rights comprise a number of obligations, and the UNCRC articles concerned are as follows:

- Article 12: Right to express views in matters affecting the child

- Article 13: Right to freedom of expression

- Article 14: Right to freedom of thought, conscience and religion

- Article 15: Right to freedom of association and assembly

- Article 30: Right of children of minority communities and indigenous populations - Article 30: Right of children of minority communities and indigenous populations to enjoy their own culture and to practice their own religion (De Winter 1997:33) Another article that goes hand-in-hand with children's right to participate is children's right to information as stated in Article 17 (Ramsden \& Vawda 2007:94-95). Access to information is critical in mobilising enabling environments for children's meaningfu participation. The same self-determination rights to 'non-discrimination or equality; 
The UNCRC (1989) suggests three over-arching principles as a general framework for implementing children's right to survival, development, protection and participation. The first principle is non-discrimination. It is founded on the human rights principle of equality, which emphasises that all people, including children, are of worth and value and deserves to be treated with dignity and respect. The second principle, namely that of the best interest of the child, acknowledges the heterogeneity of childhoods and responds to the contextspecific needs and circumstances of the individual child in the web of human relations. The third principle is that of inclusion and participation as a basic human right. Based on this principle, children are acknowledged and respected as full members of their communities and active citizens in society who have a right to participate and voice their opinions in decisions affecting their life.

The UNCRC (1989) principles are set in a context of parental direction and guidance (Article 5) and the evolving capacities of children (Article 5), which partly determine the interpretation of the above general principles.

The African Charter on the Rights and Welfare of the African Child (Organisation of African Unity 1999) has the same above-discussed three principles, with the right to life, survival and development added as the fourth principle. Ramsden and Prest Talbot (2009:9) see these principles as '... the basis for the children's section (S28) in the Bill of Rights in the South African Constitution...'.

Many individual authors also contributed to this conversation. In support of children's rights, the late Sturm (1992) raised awareness about the suffering and rights of children. He strongly advocated for viewing children as creative participants and citizens in the global community, capable of contributing towards the richness of community. He therefore pleaded in his work for a loving context for the lives of children. Sturm (1992:6) saw love as '...the impetus to emancipate children from conditions of suffering through the effectuation of their rights'. He argued as follows:

[C]hildren are deserving of their own form of a theology of liberation as a means of giving voice to their suffering and in turn articulating the character of their rights. ... [A] theology of liberation forces us to attend as well to those systemic conditions of our common life - economic, social, political - whose effects on the lives of children are at least equally violative of the meaning of childhood as direct physical abuse, if not more so. The lives of children are sharply delimited and irreparably damaged and degraded by structural forces which are susceptible to transformation, but sustained by those in positions of power. (pp. 1-2)

(footnote 4 continues...)

freedom of expression; information; protection of privacy; freedom of thought religion and conscience and participation in cultural life' are found in regional law and in the Constitution (Jamieson 2011:25). However, the Children's Act is, according to in the Constitution (Jamieson 2011:25). However, the Children's Act is, according to Jamieson (2011:26), the only legislative document in either national or international w that uses the wording 'the right to participate'

Every child that is of such an age, maturity and stage of development as to be able to participate in any matter concerning that child has the right to participate in an appropriate way and views expressed by the child must be given due consideration (Children's Act 38 of 2005, Section 10).
In accordance with Sturm's (1992) plea for children's own form of a theology of liberation, we suggest that a rightsbased emphasis in doing child theology implies an ongoing theological commitment and public theological engagement concerning children's rights. Any real acknowledgement of children's rights, however, requires implementation in practice. Grass and Grass (in Human 1998) warn about the rights of children as follows:

$[A] n$ idea, an ideal, at best an affirmation of principle ... does not help children until it is put into practice. If it is ignored, obstructed, or perverted, it does no good; in fact, it may do harm, because many people will take the words for the act and think that because the words have been spoken the condition of children's lives has changed. (p. 46)

A rights-based emphasis thus implies being publicly and actively involved in the real politics that influences children's everyday lived realities (cf. Palm 2018). De Beer (2008:51-56) suggests a number of ways to express justice. These include involvement in the fair and equitable distribution of resources; restitution - making right what is wrong; restored relationships/restorative justice for both victim and offender; policy-making and renewal processes to contribute to policies that serve children's best interests; inclusion of children and identification of discriminatory actions towards children that exclude them as rightful members of society; and working for lasting peace, which is 'just, ensuring a fair distribution of resources, equal access to opportunities, sharing of power, and the protection of socio-economic, political and other human rights'.

Janet Prest Talbot set an example of what it means to mobilise from the bottom up in order to provide an enabling environment for implementation of child rights and for children to participate meaningfully in matters pertinent to their lives. She provided many communities in South Africa with valuable resources and information about children's rights with the aim to strengthen circles of support and responsibility for children and their well-being. One of the resources Talbot developed is a trainer's manual for adults 'as they are the key "duty bearers" responsible for ensuring that children's needs and rights are made a reality'. The introduction to this manual (Ramsden \& Vawda 2007) states the following:

We would like them [adults] to see that every right mentioned, is a right we would desire for our own children. We hope that, in the spirit of Africa, we will see every child as our own child, and strive to serve their best interests, as they deserve. We believe that when we make children's rights a reality, we are building a more humane society for everyone. (p. 2)

The title of the manual, Making children's rights a reality: Building a child-friendly society using a children's rights approach, reflects the broader cause Prest Talbot was committed to. The publication emphasises the importance of entrenching the rights of children not only in South Africa's policies and legislation but also in the deep fabric of society. This highlights that children and adults should become partners in advancing a child-friendly society. 
Prest Talbot brought liberating understandings of children and their rights as found in the work of De Beer (2008), Mannion (2007); Melton (2005) and Sturm (1992). All these authors understood rights in the context of the wholeness and richness of the community and broader society, with adults and children as co-creators in the making and transformation of spaces. Sturm (1992) described this as follows:

$[R]$ ights are not, in any simple way, claims over against the community. They are more adequately understood as a form of relationship among members of the community, a form of relationship supportive of diversity and difference. Where rights are jeopardised, the character of the community is threatened. That is rights - including welfare rights and rights to self-determination as interdependent principles constitutive of social interaction - enhance the creative freedom of each person not only for that person's sake, but for the entire community. (p. 12)

Along the same line, Mannion (2007) in his article, 'Why "listening to children" and children's participation needs reframing', suggests the following:

$[P]$ olicy, practice and research on children's participation are better framed being fundamentally about child-adult relations and that the emerging field would benefit from becoming more sensitive to socio-spatial aspects. [...] The goal for a reframed children's participation project could be to understand better how child-adult relations and spaces get constructed and how they can be improved. (p. 405)

Prest Talbot's work reflects a clear understanding that the discourses of child justice, children's rights and their participation and citizenship are in essence about the power dynamics of adult-child relationships in a broader cultural and societal context. ${ }^{5}$ Prest Talbot (2010) encourages us the following:

[To] courageously shed the dehumanising stuff of our cultures. But, more importantly create more humanising practices built on the best of what our cultures are and what modern society has to offer. Culture is dynamic and we need to be reflective and deliberately reconstructing it. It is a 'right' after all! Look for good stories, role models and rites that demonstrate human rights in our cultures. Send stories to CRC to support the idea that there are creative elements that uphold children's rights in our cultural practices. (p. 1)

This is a challenge we want to take up as we engage with children to work in partnership towards realisation of their rights. Transforming dehumanising cultural beliefs and practices based on a rights-based emphasis and a relational and socio-spatial perspective has the potential of bringing forth emancipatory adult-child relationships in search for a humane and just society for all.

5.Prest Talbot invested as much energy in sensitising children about their rights and empowering them as she did with adults. In this way she emphasised the importance of reciprocal adult-child relationships where the mutual give and take of both adults and children alke are acknowledged. She was certain of the possibility of ongoing transformation and embodied this belief and hope in facilitating the co-construction of child--adult relationships in more humane spaces of living.

\section{Emancipatory methodologies of doing theology and research: Mediating justice and freedom Towards emancipatory methodologies}

Janet Prest Talbot's work resonates with Melton's (2005) rights-based framework for research and advocacy, which can serve as a starting point in a move towards an emancipatory methodology. Melton stresses that a rightsbased approach to research should seek to build or strengthen humane communities that include children as persons. With regard to the process of research, Melton (2005:649) argues that 'the approach to research should itself be consonant with respect for participants' dignity. The medium is the message'. He (Melton 2005:655) provides an example of what the potential benefits of rights-based initiatives may entail by referring to the initiative 'Strong communities for children in the Golden Strip.

The project focused on a collective effort to prevent child abuse and neglect by encouraging collective responsibility for children's well-being. Melton points out that 'the most extraordinary aspect of this initiative has been that the usual divisions of race, class, religion and politics have been transcended' (Melton 2005:655). A research context and process should therefore be embedded in a vision for more just and humane communities in which children are treated like people in trustful adult-child relationships.

In considering an emancipatory methodology of doing theology and research with children, we also draw from the wisdom of Sharlene Swartz in this regard, and, more specifically, from a co-authored piece by Swartz and Nyamnjoh (2018). They distinguish between interactive, participatory and emancipatory approaches as a continuum, cautioning against equating these similar but qualitatively different approaches. Swartz and Nyamnjoh (2018) write the following:

We argue that as we move from interactive to emancipatory research, we attain higher degrees of ownership of the research by the stakeholders whose lives are affected by the problem being studied.

These higher levels of ownership represent a process in which research is transformed by the reallocation of power between researcher and researched until the point where the traditional researcher simply retains only the role of facilitator. (p. 1)

Further, Swartz and Nyamnjoh (2018) describe it in terms of degrees of ownership as follows:

[I]nteractive research is owned by the researcher, whilst participatory research is owned by both researcher and the researched. In emancipatory research, the research belongs to the researched. Put simply and from the perspective of the traditional researcher, ownership or power along this continuum transitions from mine to ours to theirs. (p. 1)

Swartz and Nyamnjoh (2018) continue to provide a very helpful differentiation between these three approaches. 
Interactive approaches use various creative methods and techniques to allow research participants to 'tell their lives' (p. 2), and although there is a real measure of co-ownership of the process, the research participants are not full participants in the sense of research subjects.

In participatory approaches, this relationship shifts to a subjectsubject relationship, research now being done 'with those affected, rather than on those affected' (Swartz \& Nyamnjoh 2018:2). Some of the benefits of this approach include capacity-building of those affected, inclusion and diversity in participation, and empowerment of the communities being researched (Swartz \& Nyamnjoh 2018:2). However, the power ultimately still lies with the researcher.

Emancipatory approaches are qualitatively different in terms of their engagement with concerns of power and oppression. Arising from critical theories and feminist thought, emancipatory approaches have 'the desire to engage in political action to create change' (Swartz \& Nyamnjoh 2018:2 with reference to Rose \& Glass 2008). The role of the researcher therefore changes from control over the process to a facilitating role (cf. Garbutt 2009), providing a 'forum where analysis, reformulation, and recognition of emancipatory interests are supported and encouraged' (Alexander 2010:603). The research participants shape the agenda in line with their aspirations. Everything from the research topic to the collection and dissemination of data are shaped by research participants to serve their needs, rather than that of the researcher' (Swartz \& Nyamnjoh 2018:3). The generation of knowledge serves the emancipatory agenda of the community themselves.

This approach understands the process of knowledge generation as the mediation of freedom (cf. Swartz \& Nyamnjoh 2018). Such freedom comes from recognition that those who experience oppression are 'better able to name their world and its oppressions, and thus transform it' (Swartz \& Nyamnjoh 2018 in reference to Freire 2000):

This is part of a radical social agenda of equality (or justice) where research and knowledge production focus on the oppressed and the voiceless. (p. 3)

Swartz and Nyamnjoh (2018:3) then offer a very helpful conclusive analysis, showing the shared commitments of all three approaches to 'inclusivity and engagement in the research process'. As opposed to some of the more traditional forms of research, they suggest that all three of these approaches are serious about how and where generated knowledge could be applied. These methodologies are committed to 'mutual and sustainable learning, self-reflection, the co-construction of knowledge and the empowerment of research participants' (Swartz \& Nyamnjoh 2018:3).

Placing these approaches on a continuum is helpful as it serves to differentiate these methods in terms of 'varying degrees of inclusion, power and ownership' (Swartz \& Nyamnjoh 2018:3). Such differentiation is helpful to critically assess one's own approach in terms of how emancipatory it really is.
Does the research contribute in concrete and measurable ways to a greater sense of justice and freedom? Swartz and Nyamnjoh (2018:3) clearly submit that 'if the goal is justice and freedom', then an emancipatory approach is ideal.

Swartz and Nyamnjoh (2018:4-9) present four case studies of actual research, mostly with young people in Africa, and use this as a way of assessing the extent to which these research projects represented various approaches on the continuum. In conclusion, they arrive at the following five critically important questions:

- 'What will it take in our own practices to invite participants to set their own research agendas and what is needed to create a space for self-emancipation after the research process is over?' (Swartz \& Nyamnjoh 2018:10)

- How can some of the currently used interactive methods be deepened and reframed to solicit a greater sense of ownership from participants in determining the research agenda and outcomes? (cf. Swartz \& Nyamnjoh 2018:10)

- How can institutions such as universities and funding bodies be educated to understand the importance of both the continuum, but, even deeper, research as an emancipatory practice? (cf. Swartz \& Nyamnjoh 2018:10)

- How can research participants 'be helped to see the potential of emancipatory research and aided to develop skills to begin to set their own research agendas and to be able to resist having research imposed upon them'? (Swartz \& Nyamnjoh 2018:10)

- How can theological research, 'where conventionally scant attention has been given to research methods generally' embed itself in a deep understanding of the approaches and methods represented in this continuum, and, ultimately, embrace research as freedom, as the 'ideal of faith-based researchers'? (Swartz \& Nyamnjoh 2018:10-11)

\section{The agency and participation of children in doing theology and research}

Having spent considerable time to unpack the continuum as proposed by Swartz and Nyamnjoh (2018) as a way of introducing and advocating for emancipatory methodologies in doing theology and research with children, we have to now consider to what extent this might be a viable possibility for doing child theologies.

In a previous section, we considered a rights-based approach to child theology, deeply committed to child justice. We then gave glimpses into the life and work of Janet Prest Talbot, who, in all she undertook, embodied and modelled a deep yearning for child justice, expressed very concretely and respectfully by how children are co-owners of the table.

Prest Talbot might not have used the term 'emancipatory' in her approach, but her allowance for child participation and her commitment to children's rights work in our minds definitely represents an emancipatory rather than a participatory approach, to borrow from Swartz and Nyamnjoh (2018). Interestingly, although she does not reflect 
much on theory, Prest Talbot had her roots in feminist thought, a feminist reading of the Bible and a feminist outlook on the household of God. Maybe similar to the roots of emancipatory approaches in research, it is suggested that Prest Talbot's feminist faith might have laid a solid foundation for her approach to children's work.

Prest Talbot (2010:1) firmly held that '[p]articipation is more than big meetings or feedback sessions. It is a lifestyle of respect, inclusion and acknowledgement of children in every space we might find them'. The purpose of such a lifestyle is 'to see children being heard, acknowledged and empowered through participating in the matters affecting their lives' (p.1). It relates to all spheres of life, including 'family, community, our organisations, institutions and the nation as well' (p. 1).

This is completely aligned with the description of an emancipatory approach where those affected by the research, experience depths of empowerment, and increased ownership in relation to all matters pertaining to their lives. In her work she endeavoured to call forth the creativity, wisdom and agency of children as full human beings and participants at the table.

Ramsden and Prest Talbot (2009:9) regarded the inclusion and belonging of children as 'a human right' that 'underlies all human relationships' as paramount. They suggested that children's full inclusion is important 'as it is through participation in human relationships that they learn to be capable, responsible and caring members of society'. They consider children's ability to be 'capable, responsible and caring members of society' not as a dream for when they become adults but as an expression of the agency of children while still very young.

They develop this idea of children's agency even further when they say the following (Ramsden \& Prest Talbot 2009):

Child participation is a partnership between adults and children with the aim of building trust and co-operation so that together they can help to build a better world. (p. 14)

In this work of Ramsden and Prest Talbot (2009), their sense of children's agency and participation is that of shared ownership for building a world of justice and freedom. In this sense their understanding of children's work is truly emancipatory.

At the same time, however, Prest Talbot (2010) had a very sober view of society, acknowledging the incongruence of South African child laws insisting on child participation on the one hand, and yet the inability of adults to find their way in this new territory, on the other hand. Nine years after she stated this, not much has changed. In legal settings, school environments, health care institutions, churches, community development organisations and spatial planning processes, children should be involved when matters are discussed that potentially affect their lives. And yet Prest Talbot (2010) said:
If adults have not been liberated from 'antagonistic' attitudes towards children, children's freedom would be limited in terms of how they are allowed to express themselves.

In doing theology with children, we have to consider the insights of both emancipatory approaches as described by Swartz and Nyamnjoh, and the emancipatory practices as they were embodied in the work of Prest Talbot. Faith communities are notorious for keeping children separate and treating them as 'not fully human yet'. Both in churches and communities across South Africa, those doing theology with children, engaged in ministry with children, or committed to faith-based research with children, should consider the shifts that are required if the work with children is to be truly emancipatory: Calling forth the participation and agency of children in ways that will help set them and us free to be fully human, together. We have to learn and practice innovative research methods that facilitate children's ownership of processes that affect them. We should, in line with Prest Talbot's creative contributions around play (cf. Prest Talbot 2008; Prest Talbot \& Thornton 2009) consider playful research methods, play as research, and research as play. ${ }^{6}$

\section{The ethics conundrum}

The previous sections spoke in lofty terms of the ideals of child participation and child emancipation in doing research and theology with children. In practice, it is often much more complex. The ethics standards can sometimes paralyse research, creating a conundrum for researchers. Although we acknowledge the practical difficulties, we assert at the same time the importance of children's research and the participation of children in constructing knowledge about children in ways that could be mutually emancipatory for both the children and the adult researcher-theologians. In order to implement this assertion, we examine in this section the guidelines that offer safeguards.

\section{Who are the children?}

From a legal perspective, children have minority status because of their emotional, cognitive and physical immaturity and their limited life experience (South Africa Department of Health (DoH) 2015:27). However, the ethics codes embedded in the ratified children's rights instruments, the UNCRC and the ACRWC; the South African Constitution (Act No. 108 of 1996); the Child Justice Act 75 of 2008 and the Children's Act 38 of 2005, reflect different views on children and childhood that cause tension fields with respect to ethics. Children are seen as vulnerable and in need of care and protection. At the same time, they are acknowledged as agents with the right and capacity to participate in matters pertinent to their lives.

$6 . J a n e t$ 's respect for children as persons and her gift to engage playfully with children (cf. Prest Talbot \& Thornton 2009) was widely acknowledged, also by the highly acclaimed Children's Institute of the University of Cape Town. In preparation for acclaimed Children's Institute of the University of Cape Town. In preparation for the South African Child Gauge 2010/2011 publication with its focus on 'Children as citizens: Participating in social dialogue', Janet was approached to facilitate the children's participation process. A beautiful poster that accompanied the publication was designed in collaboration with children - a process during which Janet played a key role over a series of four workshops. This publication acknowledges Janet for the set of child-friendly and playful exercises she developed and it is recommended for deepening children's and adults' understanding of participation (Jamieson et al. 2011). 
The challenge then for researchers is to reflect critically and continuously on dominant and one-sided views on children and the ethics implications for doing research with children.

\section{Mechanisms to protect children}

Research ethics systems and infrastructures were put in place to ensure that South Africa's people, including children, are protected from researchers who treat them unfairly or with disrespect and that all research undertaken in the country is scrutinised for proper ethics (DoH 2015:9). For people considered as vulnerable, such as children, even more strict protective measures and regulatory authorities have been formed (DoH 2015:27-35).

The National Health Act ensures a strictly regulated research environment as it stipulates that research ethics committees that review research with vulnerable human participants must be registered with the National Health Research Ethics Committee. Although the DoH provides the regulatory and statutory framework for ethical health research, it is clearly stated that the core ethical principle of beneficence and non-maleficence, distributive justice (equality) and respect for persons (dignity and autonomy) - apply to all forms of research that involve human participants (DoH 2015:2, $7-9$, 14). The national policy for conducting research responsibly and ethically, tailored to South Africa's needs, is stipulated in 'Ethics in Health Research: Principles, Processes and Structures' (DoH 2015:2).

Consequently, processes of doing research with children are subjected to norms and standards (DoH 2015:15-17) and minimum conditions or critical considerations when research involves child participants (DoH 2015:29-35). The following minimum standards are relevant to all theologians and researchers desiring to engage in research with children.

\section{Relevance and value}

Research with children should investigate a problem field relevant and of value to children (cf. Zimmermann 2018:253-255). Doing theology and research with children should seek to improve the living conditions, the well-being and life possibilities of children. If the research does not have this aim when viewed from a child's rights, social justice and embodied public theological perspective, it is unlikely that the involvement of children in the research could be ethical.

\section{Scientific integrity}

A sound research design and methodology are critical for research integrity (cf. Zimmermann 2018:252-256). Poor design and inappropriate methods do not serve the best interests of children.

When applied to theological research, this means that researchers should consider children's views just as meaningful and valuable during the phases of theological or biblical reflection and action (phases in which alternative or preferred realities are imagined and a theological vision and strategy for action is constructed) as when describing and analysing children's world through their eyes and voices. Zimmermann (2018) suggests the following in her work on 'Ethical standards in theological research involving children':

$[W]$ e should consider how to integrate children into the research process. This begins with thinking with children about which questions might be interesting and important for the research, and continues with developing a setting together. (p. 261)

Researchers should, for instance, ask themselves to what an extent and how their views of the Bible or other theological normative sources together with their hermeneutical paradigms motivate or restrict children's participation in the theological reflection phases of the research process. Are children considered as potential partners in dialogical theological and biblical interpretation processes or are these processes mainly the business of trained theologians, more specifically scholars in biblical sciences? Another concern with regard to scientific integrity of theological research with children is the God language used in the research. Is the God language neutral in terms of gender? Is the God language of such a nature that children want to join the search for understanding who God is in relation to humanity? Or do researchers use fixed or closed-ended depictions of God that may even cause barriers for children to meet their God?

\section{Role-player engagement}

When undertaking ethical research with children, various role-players should be engaged to ensure respectful treatment of child participants within their respective communities. Entering a research context in a respectful manner requires consultation with a gatekeeper or gatekeeper organisation, in other words with those who have the power to grant or deny permission for access into the potential research community. A gatekeeper, with his/her knowledge of the social, cultural and language dynamics and protocols of the context, is a critical partner in research and may increase the acceptability of the research.

A gatekeeper may also suggest a mediator to facilitate the communication between the researcher, the potential research community and child participants. Furthermore, it is recommended that an independent person should facilitate the process of obtaining informed assent to protect child participants from feeling intimidated, manipulated or coerced when taking part in the study.

\section{Fair balance of risks and benefits}

A risk-benefit analysis should precede research with children. This analysis means that the likelihood of benefit should outweigh the anticipated risk of harm or discomfort to participants. In the context of theological research with children, not only the risk of physical, emotional and psychological harm but also the possible risk of spiritual harm should be considered (cf. Zimmermann 2018:256, 262). Children can in the context of research be bullied spiritually to see the world, themselves and God in prescriptive ways. 
Put differently, children's right to freedom can be violated in research contexts driven by conservative theological or religious agendas - especially where tradition is viewed as fixed and not open to change.

Theologians and researchers who want to engage with children should ask themselves what protective measures they can put in place to ensure that children are heard in open-ended ways by not interrupting, correcting or manipulating children in their communication.

\section{Fair selection of participants}

The researcher should be able to provide evidence that the recruitment, selection, exclusion and inclusion of child participants for research are just and fair. The rationale for the selection of child participants should be based on scientific and ethics principles. Children should not be excluded unreasonably or unfairly based on unfair grounds for discrimination as stipulated in Section 8 of the Constitution, namely race, age, sex, sexual orientation, disability, education, religious belief, pregnancy, marital status, ethnic or social origin, conscience, belief or language.

\section{Informed assent}

Children are not in a legal position to choose independently whether to participate in research. Parents or guardians must provide consent or permission for researchers to approach children with information about the research and to invite them to participate. At the same time, consent or permission from parents/guardians does not negate the need for informed assent ${ }^{7}$ from children. The child's right to participate, as emphasised in the Children's Act 38 of 2005, has to be acknowledged by providing children with a choice on whether to participate or not during the entire research process.

Obtaining assent from children in South African research contexts entails clear procedures per age group. In the South African research context, where many minors do not have parents or court-appointed guardians, it is considered ethical and reasonable to designate parental substitutes in research studies of relevance to orphaned and vulnerable children. This arrangement is only justifiable when the research, involving no more than minimal risk of harm, seeks to understand and improve the living conditions and wellbeing of this significant segment of child population (DoH 2015:32-33).

Parents or guardians and other adult role players are critical in constructing safe, secure, supporting and enabling research environments that communicate respect for children's agency and rights. They have to be encouraged to share the power and responsibility for decisions about consent, permission and assent with their children (Dockett \& Perry 2011:237).

\footnotetext{
7.The notion of 'assent' indicates the agreement of those not able to give legal , parental consent is sought with children having to provide verbal assent or dissent. Written assent or dissent has to be obtained from children between the ages of 7 and 11 years after parental consent is received. Parental permission is needed before adolescents between the ages of 12 and 17 years can be approached, and negotiations can take place for them to provide or decline adolescent consent.
}

The process of facilitating children's assent with regard to their research participation is based on three pillars (Dockett \& Perry 2011:234-236; cf. DoH 2015:31). Firstly, children should have access to information tailored to their evolving capacities. Adequate and appropriate information support informed decision-making. Secondly, children's participation in research should be voluntary, which implies that children have to know that they have the freedom to withdraw from the research at any time without negative consequences. Lastly, the evolving capacities of children to make informed decisions should be respected. This acknowledges and advocates for the heterogeneity of childhoods, the contextual nature of research and the need for a situational approach to research ethics (cf. Ebrahim 2010).

\section{Ongoing respect for participants, including privacy and confidentiality}

All research participants, including children, have the right to privacy and confidentiality. Privacy in the research context has to do with who has access to personal information about the participants. Confidentiality is concerned with the disclosure of information that might identify the participant during the course of study or afterwards during the dissemination of research results and findings. Ongoing respect is also communicated by considering language and doing member-checking with child participants to ensure true representations of their voices (cf. Swartz 2011:60-61). By reporting the outcomes of research back to child participants in an age appropriate manner (cf. Viviers \& Lombard 2012:17; Zimmermann 2018:262) enable them to take full ownership of research outcomes and to act on it, especially when research is planned and facilitated as freedom, emancipation and intervention (cf. Swartz 2011).

\section{Researcher competence and expertise}

Ethics clearance is also contingent upon sufficient proof of the researchers' competency and expertise. The ethics application should explain in clear terms how a safe, supportive and enabling environment for doing research with children is ensured. Competence includes research knowledge and experience as well as evidence of appropriate research ethics training.

\section{Where do the ethics guidelines leave children?}

While recognising the necessity of universal ethics standards in the functioning of research ethics committees, we stress the importance of children's agency as a means of recognising the capabilities of children in relation to the ethics of their research participation. Given our emancipatory and rightsbased approach to doing research with children, we want to reflect on the position of children in research ethics by posing the following questions:

To what extent and how does the mandate of research ethics committees allow for children to:

1. set or shape research agendas in accordance with their needs and anticipatory aspirations? 
2. be involved in the planning of the research design and methodology (thus the form of their participation) and its execution?

3. indicate how their knowledge could be recognised optimally in knowledge production?

4. assess by themselves the potential risks, discomfort and benefits of participating in the research?

5. suggest ways of how a safe, supportive and enabling environment for children's meaningful research participation could be established and maintained?

6. voice their preference for appropriate information in order for them to make informed decisions with regard to the nature of their research participation?

7. choose pseudo names that would represent their voices?

8. challenge power dynamics and understandings of who are the experts in the world of children?

9. act on the knowledge that is constructed during the course of research within established circles of support for children after the formal research process has come to an end?

Upon considering these questions, we argue that the discourse and practice of research ethics may have liberating and emancipatory outcomes for research ethics committees, researchers and research participants, even for policy makers focusing their work on research ethics. We are convinced that children, when recognised as full partners in co-constructing research spaces, can help adult researchers to value relationships; time; dialogue; reflexivity, flexibility and uncertainty as core elements of an ethical praxis in research environments (cf. Chesworth 2018; Dockett \& Perry 2011; Ebrahim 2010; Swartz 2011; Zimmermann 2018).

\section{Ethics implications of excluding children from research that involves them}

We now turn to our concern about the ethics implications if children are excluded as subjects in research that concerns them and their well-being. In the first place, the knowledge gathered about children will be of limited to no value. Such neglect of children's knowledge results in knowledge production that merely reflects the agenda and voices of adults. No fresh theological questions will be raised, and irrelevant theological responses might be formulated for questions children do not even have. Theology about children will echo adults' concerns and ideas and researchers will miss out on opportunities to respond to children's bodily life, rights and needs with contextual theologies. This may result in neat theologies and research praxes that would remain untouched.

Secondly, such research deprives children of exercising agency in the co-construction of helpful and liberating child theologies. We will remain ignorant of children's agency and ability to act in ways that could protect their interests, enhance their own well-being and inform our sociotheological constructs. Our exclusion of children will limit our contribution to their empowerment and emancipation as active agents and role-players in their contexts of living. Our modes of doing theology will consequently silence children's voices and strengthen thinking patterns about children as objects of research and ministry; as merely vulnerable, with needs that support the protectionist position that keeps children in passive positions.

Thirdly, it will distract our attention from the importance of practising public modes of theology where attention is given to building just and free societies with children as active partners and responsible members of society. Excluding children makes it impossible for us to listen to children and hear their views on how we can act on transforming their living conditions, well-being and life possibilities. This would mean that children are excluded from the anticipated benefits that research may hold for communities. At the same time, we might get stuck in practising private theologies that keep us safe in our theological comfort zones.

As a result, we can isolate and exclude ourselves from collaborative forms of doing research with children as part of interdisciplinary; multidisciplinary and trans-disciplinary teams.

Last, but not the least, adult researchers and theologians will miss out on chances to be liberated and emancipated by children. We will miss out on liberating experiences of interdependence, mutuality, difference and reciprocity in our being human with children. By excluding children in contexts of research, we will miss out on opportunities to welcome real children in concrete times and spaces in God's name.

Consequently, we will miss out on encountering God in new ways in research spaces.

\section{Co-constructing theological responses to children's lives and worlds}

Co-constructing theological responses to children's lives and worlds implies collaborative theological work involving academics, activists, practitioners and children to find and live responses to the life worlds of children together.

The continuum of interactive, participatory and emancipatory research approaches could be helpful tools in conceptualising, designing and implementing collaborative child theology processes. The summative questions raised by Swartz and Nyamnjoh (2018) could help deepen reflection on what collaborative - and eventually emancipatory - methodologies might look like. Here, we translate their questions for the topic at hand, namely doing theology and research with children:

- What will it take, when doing theology with children, to involve children to set their own research agendas, and how can the self-emancipation of children continue after the research is over? 
- How can creative and interactive methods that are used with children when doing child theology be refined and reframed to ensure a greater sense of ownership among children in determining the research agenda and outcomes?

- How can those engaged in child theology educate universities and funding bodies on the importance of research with children as an emancipatory practice?

- How can children be helped to see the potential of emancipatory research and aided to develop skills to begin to set their own research agendas?' And how can be children supported with capacity 'to resist having research imposed upon them'? (Swartz \& Nyamnjoh 2018:10)

- How can those of us who are committed to children and to doing theology and research with children, deepen our own understanding of the approaches and methods represented on Swartz and Nyamnjoh's continuum (2018)? How can we embrace and practice research as the mediation of freedom, in this case for and with children, as the ultimate vision and goal of our work?

Mapping out this continuum enables researchers to better describe and evaluate where their work currently is and where they would like it to be in the future and to ask the right questions in order to get there.

The contribution of Prest Talbot should be considered in this regard. She modelled collaborative approaches and embodied a commitment to emancipatory action with children. She practiced uncompromisingly what many only reflect upon theoretically. Her practical work was underpinned by deep theoretical understandings and commitments, and her theoretical contributions were underpinned by deeply immersed action. She embodied a praxeological approach in her life and work, which is by definition liberationist.

Unfortunately, her untimely death prevented her from documenting and sharing even more about her own work. We would have loved to ask her to explain more about the fusion of her faith, feminist commitments and desire to see justice for children. We would have loved for her to educate theologians, child activists and child practitioners in ways that could model emancipatory spaces as she so aptly created them. We would have loved to have many more people experience the freedom that comes with embracing the agency of children, as fully human, and sources of great wisdom and power, through the ways in which she celebrated children. She left a legacy upon which we should build.

\section{Conclusion}

The aim of this article was to address three concerns: (1) A general absence of children from the agendas of dominant theological institutions; or if children are included, mostly in very ecclesial terms, excluding children who are not participating in faith communities; (2) the necessity of anepistemological shift so that researchers value children as subjects with lived experience, knowledge and a sense of agency; and (3) a conviction that emancipatory methodologies should be conceptualised and practiced for doing theology and research with children as an expression of a theological commitment to freedom and justice for all children.

In this collection of articles, different voices grapple with an understanding of emancipatory methodologies in theorising about research with children. It is a rich combination of theological, interdisciplinary and trans-disciplinary contributions.

This article forms part of a collection of nine articles, seeking to contribute to scholarly engagement in the field of child theology, as an expression of the commitment of a network known as Child Theology Africa.

The first five articles in the collection - including this one by De Beer and Yates - focus on the paradigmatic or methodological aspects of an emancipatory approach. Motha, Makgamatha and Swartz write about emancipatory research methodologies with children in the African context, considering both practical possibilities and overcoming concrete challenges. Dillen focuses on ethical and methodological issues in research with children as theologians and Grobbelaar explores the emancipation of the adult researcher in the process of doing research with children. Adawu theologises hope with children through what he speaks of as multimodal narrativity.

The other four articles consider emancipatory possibilities, focusing on real situations in different local contexts. Chisale considers the reality of unaccompanied refugee minors in South Africa and their participation in processes of pastoral care. Koch, Yates and Kitching explore adolescent girls' voices on their need for education on sexuality and emphasise the importance of mutual sexual emancipation of both adolescent girls and adults. Talbot and Saneka reflect on the way in which the children of the Scott's Farm Scouts Club found their own voice and agency. In their article, Johannissen, Yates and Van Wyk describe children's participation in multidisciplinary meetings in a child and youth care centre, exploring the emancipatory value of listening to children.

We deem the conversation opened up by this collection of articles as crucial, on a continent where half of the people are children, mostly excluded from decisions and processes that affect their lives directly.

\section{Acknowledgements}

The authors acknowledge the professional services of our language editor, Christien Terblanche, who works at Cum Laude Language Practitioners.

\section{Competing interests}

The author declares that they have no financial or personal relationships which may have inappropriately influenced them in writing this article. 


\section{Authors' contributions}

S.D.B. and H.Y. equally contributed to the writing of this article.

\section{Funding information}

The research received no specific grant from any funding agency in the public, commercial or not-for-profit sectors.

\section{Data availability statement}

Data sharing is not applicable to this article as no new data were created or analysed in this study.

\section{Disclaimer}

The views expressed in the submitted article are that of authors and not an official position of the North-West University.

\section{References}

Alexander, I.M., 2010, 'Emancipatory actions displayed by multi-ethnic women: "Regaining control of my health care",', Journal of the American Academy of Nurse Practitioners 22(11), 602-611. https://doi.org/10.1111/j.1745-7599.2010. 00554.x

Ansell, N., 2005, Children, youth and development, Routledge, London.

Chesworth, L., 2018, 'Embracing uncertainty in research with young children', International Journal of Qualitative Studies in Education 31(9), 851-862, https:// doi.org/10.1080/09518398.2018.1499982

De Beer, S., 2008, The gospel, children and the city, 2nd edn., Imagine, Pretoria.

De Winter, M., 1997, Children as fellow citizens: Participation and commitment, Radcliffe Medical Press, Oxford.

DeVries, D., 2001, 'Toward a theology of childhood', Interpretation 55(2), 161-173. https://doi.org/10.1177/002096430005500205

Dockett, S. \& Perry, B., 2011, 'Researching with young children: Seeking assent', Child Indicators Research 4(2), 231-247, viewed 08 February 2018, from https://linkspringer-com.nwulib.nwu.ac.za/article/10.1007\%2Fs12187-010-9084-0.

Ebrahim, H.B., 2010, 'Situated ethics: Possibilities for young children as research participants in the South African context', Early Childhood Development and Care 180(3), 289-298, https://doi.org/10.1080/03004430701822958

Freire, P., 2000, Pedagogy of the oppressed, Bloomsbury, New York.

Garbutt, R., 2009, 'Let's talk about sex: Using drama as a research tool to find out the views and experiences of young people with learning disabilities', Creative Approaches to Research 2(1), 8-21, https://doi.org/10.3316/car0201008

Hall, K., Richter, L., Mokomane, Z. \& Lake, L. (eds.), 2018, South African child gauge 2018,Children's Institute, University of Cape Town, Cape Town.

Harris-Curtis, E., 2003, 'Rights-based approaches issues for NGOs', Development in Practice 13(5), 558-564. https://doi.org/10.1080/0961452032000125956

Human, C.S., 1998, 'Die invloed van die begrip kinderregte op die privaatregtelike ouer-kind verhouding in die Suid-Afrikaanse reg', PhD thesis, Department of Law, Stellenbosch University, Stellenbosch.

International Save the Children Alliance, 2002, Child rights programming: How to apply rights-based approaches in programming: A handbook for the International Save the Children Alliance members, International Save the Children Alliance, London.

Jamieson, L., 2011, 'Children's rights to participate in social dialogue', in L. Jamieson, R. Bray, A. Viviers, L. Lake, S. Pendlebury \& C. Smith (eds.), South African child gauge 2010/2011, pp. 22-29, Children's Institute, University of Cape Town, Cape Town.
Jamieson, L., Bray, R., Viviers, A., Lake, L., Pendlebury, S. \& Smith, C. (eds.), 2011, South African child gauge 2010/2011, Children's Institute, University of Cape Town, Cape Town.

Mannion, G., 2007, 'Going spatial, going relational: Why "listening to children" and children's participation needs reframing', Discourse 28(3), 405-420, viewed 23 November 2012, from https://dspace.stir.ac.uk/bitstream/1893/916/1/ Discourse\%20Article\%20Mannion\%202007.pdf.

Melton, G.B., 2005, 'Treating children like people: A framework for research and advocacy', Journal of Clinical Child and Adolescent Psychology 34(4), 646-657. https://doi.org/10.1207/s15374424jccp3404_7

Organisation of African Unity, 1999, African charter on the rights and welfare of the child, viewed 15 April 2019, from https://www.achpr.org/files/instruments/child/ achpr_instr_charterchild_eng.pdf.

Palm, S., 2018, 'Always reforming? Nurturing a church for human rights in South Africa', Stellenbosch Theological Journal 4(1), 321-346. https://doi.org/10.17570/ stj.2018.v4n1.a15

Prest Talbot, J., 2008, Play active: Every child's right. Handbook for organizing 'play active' play days, Children's Rights Centre, Durban.

Prest Talbot, J., 2010, Including children: Child participation workshop, Children's Rights Centre, Durban.

Prest Talbot, J. \& Thornton, L., 2009, A chance to play: A manual promoting play for children in South Africa, A Chance to Play, Braamfontein, Johannesburg.

Ramsden, N. \& Prest Talbot, J., 2009, Including children: Guidelines on ethical practice in fulfilling children's rights to participation, Children's Rights Centre, Durban.

Ramsden, N. \& Vawda, C., 2007, Making children's rights a reality: Building a childfriendly society using a children's rights approach: Trainer's manual, Jacana Media, Johannesburg.

Republic of South Africa (RSA), 1996, The Constitution of the Republic of South Africa, Act 108 of 1996, Government Printer, Cape Town.

Republic of South Africa (RSA), 2005, Children's Act 38 of 2005, Government Printer, Cape Town.

Republic of South Africa (RSA), 2008, The Child Justice Act 75 of 2008, Government Printer, Cape Town.

Rose, J. \& Glass, N., 2008, 'The importance of emancipatory research to contemporary nursing practice', Contemporary Nurse 29(1), 8-22. https://doi.org/10.5172/ conu.673.29.1.8

South Africa Department of Health (DoH), 2015, Ethics in health research: Principles, processes and structures, 2nd edn., Government Printers, Pretoria.

Sturm, D., 1992, 'On the suffering and rights of children: Toward a theology of childhood liberation', Cross Currents 42(2), 149-173.

Swartz, S., 2011, "Going deep" and "giving back": Strategies for exceeding ethical expectations when researching amongst vulnerable youth', Qualitative Research 11(1), 47-68, viewed 08 February 2018, from https://qrj.sagepub.com.

Swartz, S. \& Nyamnjoh, A., 2018, 'Research as freedom: Using a continuum of interactive, participatory and emancipatory methods for addressing youth marginality', HTS Teologiese Studies/Theological Studies 74(3), a5063, https://doi. org/10.4102/hts.v74i3.5063

United Nations Convention on the Rights of the Child (UNCRC), 1989, United Nation convention on the rights of the child, viewed 15 April 2019, from https://www2. ohchr.org/english/law/pdf/crc.pdf.

Van der Ven, J., Dreyer, J. \& Pieterse, H., 2003, 'Is there a church for human rights?', Journal of Empirical Theology 14(2), 20-52. https://doi.org/10.1163/15709 2501X00073

Viviers, A. \& Lombard, A., 2012, 'The ethics of children's participation: Fundamental to children's rights realisation in Africa', International Social Work 56(1), 7-21. https://doi.org/10.1177/0020872812459066

Yates, H., 2010, 'Childhood and child welfare in a social development context: An exploratory perspective on the contribution of the religious sector', in I. Swart H. Roche, S. Green \& J.C. Erasmus (eds.), Religion and social development in postapartheid South Africa: Perspectives for critical engagement, pp. 153-174, Sun Press, Stellenbosch.

Yates, H. \& Swart, I., 2010, 'The rights of children: A new agenda for practical theology in South Africa', in I. Swart, H. Roche, S. Green \& J.C. Erasmus (eds.), Religion and social development in post-apartheid South Africa: Perspectives for critical engagement, pp. 225-242, Sun Press, Stellenbosch.

Zimmermann, M., 2018, 'Respecting boundaries: Ethical standards in theological research involving children', in M. Steinhäuser \& R. Øystese (eds.), Godly play: European perspectives on practice and research, pp. 248-265, Waxmann, Münster. 